\title{
Seedling emergence and establishment of Pinus sylvestris in the Mongolian forest-steppe ecotone
}

\author{
Choimaa Dulamsuren • Markus Hauck • \\ Christoph Leuschner
}

Received: 6 August 2012/ Accepted: 27 November 2012/Published online: 14 December 2012

(C) The Author(s) 2012. This article is published with open access at Springerlink.com

\begin{abstract}
The potential of Scots pine (Pinus sylvestris) for regeneration and encroachment onto dry grasslands in the forest-steppe ecotone was experimentally studied at the south-eastern distribution limit of the species in Mongolia. The experiment consisted of a sowing and planting (2-year old seedlings) assay at two different distances from the forest line and manipulation of the water supply by irrigation in one half of the replicate plots. Seedling emergence was strongly inhibited by post-dispersal seed predation (between 50 and $>90 \%$ of the seeds were apparently consumed) and by drought. Seedling survival was limited by drought and phytopathogenic fungi that infected the needles. Herbivory by insects or rodents, a key factor for seedling mortality in Larix sibirica, the most frequent tree species in Mongolia's forest-steppe ecotone, was of little importance in Scots pine, probably due to the production of efficient allelochemicals. The potential of Scots pine to regenerate in Mongolia's forest-steppe ecotone and to encroach onto the steppe is very limited and mostly restricted to the immediate vicinity of the forest; it might even decrease in future in the face of climate warming. The observed dependence of seedling emergence and
\end{abstract}

Ch. Dulamsuren $(\bowtie) \cdot$ M. Hauck · C. Leuschner Department of Plant Ecology, Albrecht von Haller Institute of Plant Sciences, University of Göttingen, Untere Karspüle 2, 37073 Göttingen, Germany e-mail: dchoima@gwdg.de

M. Hauck

e-mail: mhauck@gwdg.de survival on soil moisture suggests that regeneration outside the forest may only be successful in exceptionally moist years. Livestock grazing is certainly an additional limiting factor for Scots pine regeneration in Mongolia, but was not relevant in the present study area.

Keywords Scots pine - Forest regeneration Drought - Seed predation - Phytopathogenic fungi · Irrigation experiment

\section{Introduction}

Scots pine (Pinus sylvestris L.) is the most widely distributed tree species in the northern hemisphere. Its natural range includes the boreal and temperate forest zones of most of Eurasia (Hultén and Fries 1986). While Scots pine may cover large areas in boreal forests, especially at disturbed sites and in more continental climates, it is restricted to marginal habitats in terms of water and nutrient availability at the southern fringe of its range. The occurrence of Scots pine both at particularly dry sites or alternatively at wet sites (bog margins) and its promotion by disturbance indicates that the species has a wide physiological amplitude, but is an inferior competitor in the interaction with other Eurasian tree species of climax forest stages in habitats with ample nutrient supply and favorable soil moisture regimes (Rehfeldt et al. 2002; Ellenberg and Leuschner 2010). 
In Central and southern North-Eastern Asia, P. sylvestris is a typical species of forest-steppe ecotones, where it occurs in the northern parts of Kazakhstan, Mongolia, and China (Wang et al. 1991; Dulamsuren 2004; Turdieva et al. 2007). In Mongolia, the species covers $5 \%$ of the total forested area of approximately $160,000 \mathrm{~km}^{2}$ (Savin et al. 1978; Tsogtbaatar 2004). Here, the species is characteristic of very dry forest communities, which often grow on mountain ridges, where they form the treeline and a transitional zone to the steppe (Dulamsuren et al. 2005). This ecological preference matches the occurrence of Scots pine in summer-dry mountain forests of the Mediterranean region, including Italy and southern Spain, in the south-western extensions of its range (Alia et al. 2001; Scalfi et al. 2009). In the recent past, such dry forests have received increased attention in conjunction with global warming.

The potential of trees to encroach onto grasslands and shrublands is largely determined by their regeneration success. Regeneration of Scots pine in dry environments depends on a multitude of abiotic and biotic factors, such as the natural variation in the fecundity among tree individuals (Debain et al. 2003), the loss of seeds through seed-eating birds already in the cones or by post-dispersal seed predators (including birds and rodents) on the ground (Castro et al. 1999), competition by other species of vascular plants in the ground vegetation (Castro et al. 2002), the provision of shelter from mechanical damage and desiccation by sparse shrub canopy (Castro et al. 2004), the access to light under shading tree canopies (Castro et al. 2005a), and the frequency and intensity of stressing agents such as fire (Núñez and Calvo 2000), fungal pathogens (Ranta and Saloniemi 2005), ungulate grazing (Hódar et al. 2008; Herrero et al. 2012), or drought (Castro et al. 2005b). These factors interact in various ways; for example, the structure of the ground vegetation strongly affects the microclimate and the exposure to seed predators. In cold and wet environments other factors, including mechanical damage by snow and wind, are highly relevant to the growth of Scots pine seedlings (van Gardeningen et al. 1991; Holtmeier and Broll 2011).

While there is detailed published work on the ecology of Scots pine at the south-western edge of its range (e.g., by Castro and coworkers), little is known about its ecological characteristics at its southern distribution limit in Central and North-Eastern Asia (Wang et al. 2005; Dulamsuren et al. 2009a). In the present study, we examined the potential of Scots pine to establish at the forest margin in the drought-affected forest-steppe ecotone and to encroach onto grasslands in front of the forest line in northern Mongolia. Dulamsuren et al. (2008) have shown for Siberian larch (Larix sibirica Ledeb.), which is the most dominant conifer at the forest-steppe boundary in Mongolia, that encroachment of steppe on southfacing slopes adjacent to forest on north-facing slopes is inhibited by a combination of the factors droughtinduced seedling mortality, herbivory by gypsy moth (Lymantria dispar L.) larvae, grasshoppers, and rodents as well as seed predation. Mature trees of Scots pine seem to be better adapted to strong drought stress than Siberian larch trees due to a more conservative water consumption resulting from a more sensitive stomatal regulation (Dulamsuren et al. 2009a). This raises the question whether regeneration on sun-exposed grasslands might be more successful in Scots pine than Siberian larch. Furthermore, the known high diversity of allelochemicals in Scots pine (Wagner and Evans 1985; Bäck et al. 2012) might provide a better protection from herbivorous insects to seedlings of Scots pine than Siberian larch. However, the perennial Scots pine needles can be expected to be more intensely infested with fungal pathogens (Kowalski 1982) than the deciduous needles of Siberian larch (Kauhanen et al. 2006), which might inhibit the establishment of pine trees.

To test the capacity of Scots pine to establish on grasslands in front of the forest line, we conducted sowing and planting experiments in the western Khentei Mountains in northern Mongolia, where Scots pine is regularly found in forest stands on mountain ridges in contact to meadow steppe on south-facing slopes (Dulamsuren et al. 2005). In our experiment, the water supply was manipulated by irrigation, while climate data were continuously recorded to examine the effect of the natural course of temperature and soil moisture. The objective of our experiment was to test the hypotheses that (1) a substantial amount of seeds is lost due to seed predation, (2) the rates of seedling emergence and survival increase with increasing soil moisture, but decrease with increasing soil temperature, (3) insect and rodent herbivory is a significant cause of seedling mortality, and (4) seedling vitality is limited by fungal pathogens. The potential effect of large herbivores, which was shown to limit the 
regeneration of Scots pine in Mediterranean Europe (Baraza et al. 2009), was excluded from the study by fencing.

\section{Materials and methods}

Study area

Field work was carried out in the western Khentei Mountains, northern Mongolia, Mandal county ("soum") in the province ("aimag") of Selenge near Khonin Nuga Research Station $\left(49^{\circ} 04^{\prime} 48^{\prime \prime} \mathrm{N}, 107^{\circ} 17^{\prime} 15^{\prime \prime} \mathrm{E}\right.$; 950 m a.s.l.; map published in Dulamsuren et al. 2005). The research station is located $130 \mathrm{~km}$ north of Ulan Bator in the valley of the River Eroo, a tributary to the River Orkhon. Geologically, the Khentei mainly consists of Proterozoic and Paleozoic rocks, especially of granite. Permafrost is limited to forests on northern slopes. The climate of the Khentei Mountains (ca. 900-2800 m a.s.l.) is characterized by the Asiatic anticyclone in winter, which typically has its center southwest of Lake Baikal and causes dry and cold winters with mean January temperatures as low as -23 to $-28{ }^{\circ} \mathrm{C}$. In summer, warm air masses from the south flow into northern Mongolia resulting in the formation of cyclones when they meet the cold air from Siberia. Mean July temperatures published from the Khentei range from 12 to $18{ }^{\circ} \mathrm{C}$. Most of the annual precipitation of $<300 \mathrm{~mm}$ is received in summer (Dulamsuren and Hauck 2008).

The vegetation of the study area is characterized by light taiga forests of Larix sibirica, Betula platyphylla, and Pinus sylvestris on north-facing slopes and different types of steppe communities on south-facing slopes (Dulamsuren 2004; Dulamsuren et al. 2005). The aspect-dependent forest lines are usually rather abrupt so that the forest line mostly equals the tree line (Fig. 1). The soils on the studied steppe slopes are Leptosols. Here, herb-rich meadow and mountain steppes are found on strongly inclined (mostly 30-45 ) shallow, stony soils, which virtually lack an organic layer, whereas Carex-rich meadow steppe occurs on deeper soils with a mostly sparse organic layer along forest edges on mountain ridges (Dulamsuren 2004). The steppe slopes and forests of the area are currently not subject to livestock grazing; in contrast to most areas of Mongolia (Lkhagvadorj et al. 2013), livestock husbandry probably never played an important role in the Khonin Nuga region (Schlütz et al. 2008).
Sample plots

Two south-facing slopes were non-randomly selected as replicate study sites. One site was at Mt. Baziin Am at $1050-1180 \mathrm{~m}$ (site $\mathrm{A})\left(49^{\circ} 2^{\prime} \mathrm{N}, 107^{\circ} 15^{\prime} \mathrm{E}\right)$, whereas the other site was Mt. Bayantogol (site B; Fig. 1b) (1020-1120 m, 49 $\left.5^{\prime} \mathrm{N}, 107^{\circ} 17^{\prime} \mathrm{E}\right)$. The studied slopes were steeply inclined and had a size of $\mathrm{c}$. $1.5 \mathrm{~km} \times 250 \mathrm{~m}$ (parallel to $\times$ perpendicular to the contour lines) at site $\mathrm{A}$ and of c. $2 \mathrm{~km} \times 350 \mathrm{~m}$ at site B. At both sites (A, B), each of one sample plot representative of the xeric open meadow steppe (Pulsatilla ambigua meadow steppe; Dulamsuren 2004; Dulamsuren et al. 2005) and of the less xeric Carex-dominated forest edge meadow steppe were non-randomly selected. The vegetation of the specific sample plots used for the present study is briefly described in Dulamsuren et al. (2008), as the same plots were used for other experiments before. The main selection criteria for sample plots were visual homogeneity of vegetation composition and stand structure. Furthermore, the distance between the two plots on a slope was to be as short as possible. Plots were rectangles of $c .1,200 \mathrm{~m}^{2}$, which were fenced with barbed wire to exclude large mammals.

\section{Irrigation}

Half of the sown seeds and planted seedlings were irrigated twice a week throughout the duration of the experiment, which lasted from mid May to late September 2006 and thus including most of the growing season. The individual subplots with seeds or seedlings were watered with 11 of nutrient-poor stream and precipitation water per irrigation. This amount of irrigation water equaled an additional weekly precipitation of $4 \mathrm{~mm}$ (Fig. 2). This amount of water addition simulated a wet year within the natural range of interannual precipitation fluctuation in the study area. During 19 weeks of watering from mid May to late September, ambient precipitation amounted to $278 \mathrm{~mm}$, whereas the irrigated subplots received a total of $354 \mathrm{~mm}$ of water, which is $127 \%$ of the natural precipitation in this period. The $278 \mathrm{~mm}$ was somewhat above the 40-yr average of $248 \pm 11 \mathrm{~mm}$ for the May to September period for the western Khentei (calculated from weather station Eroo, $49^{\circ} 48^{\prime} \mathrm{N}, 106^{\circ} 42^{\prime} \mathrm{E}, 900 \mathrm{~m}$ a.s.l.). The $354 \mathrm{~mm}$ received in the irrigated subplots was within the 

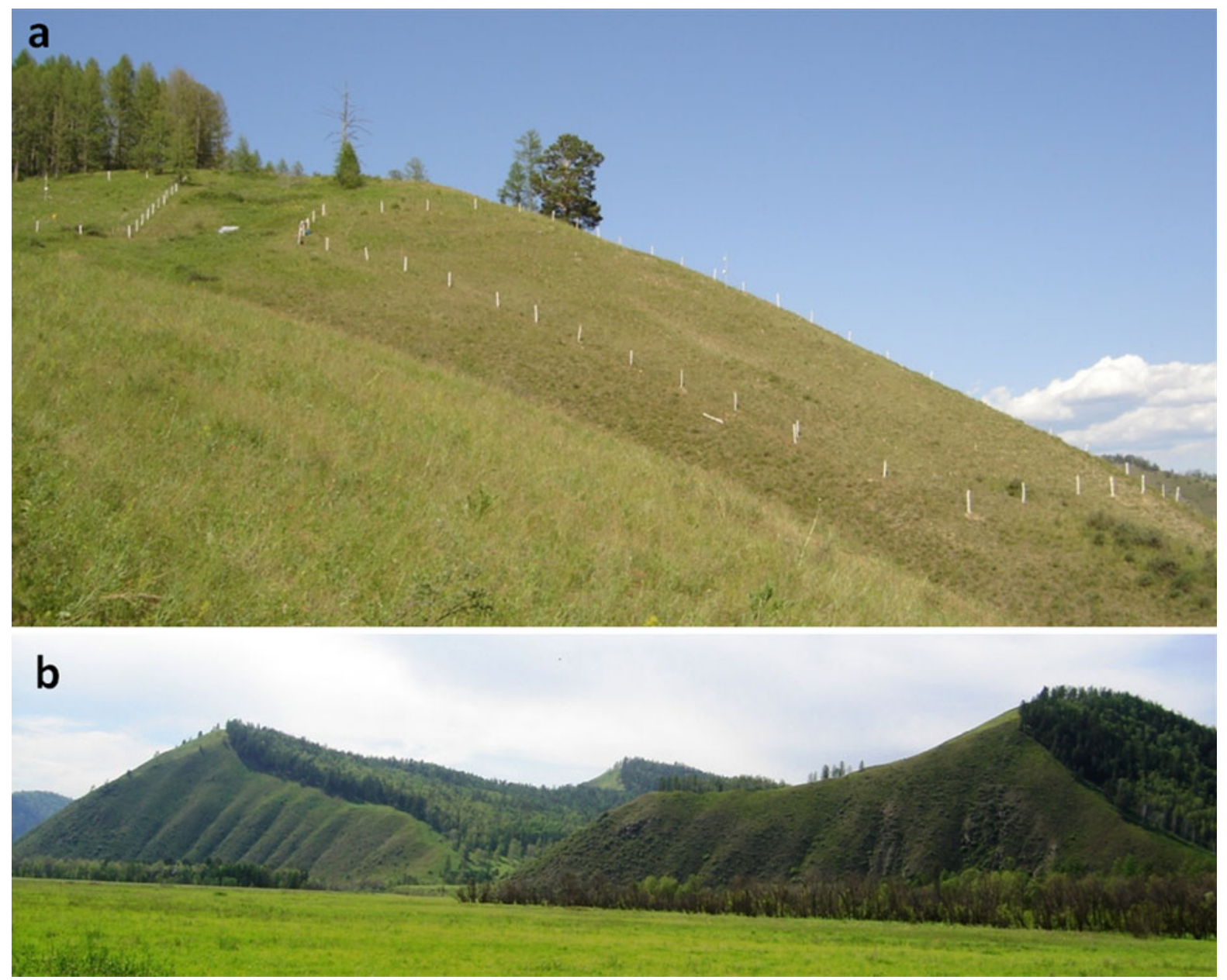

Fig. 1 Study area in the western Khentei, northern Mongolia. a Fenced plots for sowing and planting experiments on the open meadow steppe (on the right) and near the forest edge (left).

natural range of 137-409 mm (May to September precipitation). The moisture level of the irrigated subplots simulated a wet year as it occasionally occurs in the study area. At the weather station Eroo, years with $>350 \mathrm{~mm}$ of precipitation from May to September have occurred only five times since 1961 (viz. in $1964,1971,1973,1975,1982$ ). The effect of the irrigation on soil moisture was regularly examined in each subplot $3 \mathrm{~h}$ after watering. An ML-2x Theta soil moisture sensor (Umweltanalytische Produkte, Ibbenbüren, Germany) was used together with a $\mathrm{HH} 2$ portable logger to measure the volumetric soil water content in the upper $6 \mathrm{~cm}$ of the soil covering a soil volume of $75 \mathrm{~cm}^{3}$. Accordingly, the soil moisture significantly exceeded that of non-irrigated subplots 3 and $24 \mathrm{~h}$ after irrigation. b Distribution of vegetation types on the mountains with forests on the north-facing slopes, grasslands on the south-facing slopes and an abrupt, aspect-dependent forest line

Seedling emergence and seed predation

On each sample plot, pine seeds were sown in a row running perpendicularly to the contour lines. Ten subplots were arranged along this row $1 \mathrm{~m}$ apart. Each subplot was a square of $0.5 \mathrm{~m}^{2}$, where 10 seeds were sown as subsamples $20 \mathrm{~cm}$ apart at a depth of 5 to $10 \mathrm{~mm}$ below the soil surface. The exact position of each seed was marked with a plastic sign placed north (and upslope) of the seed position to avoid alteration of the microclimate due to shading. The lower five subplots of the row were watered twice a week, whereas the five upper subplots only received the natural precipitation. Irrigation had to be done extremely carefully to avoid surface runoff and loss of seeds. Seeds of $P$. sylvestris had been collected in 


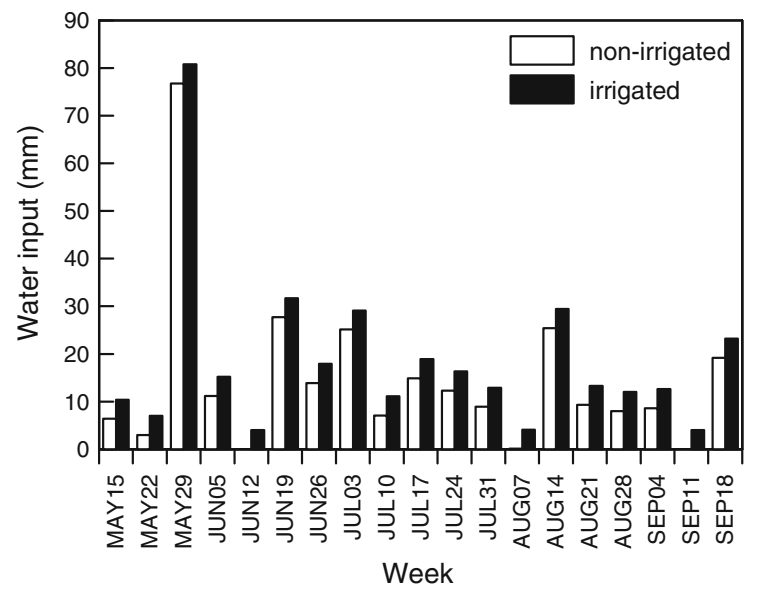

Fig. 2 Natural precipitation on non-irrigated subplots and water input on irrigated subplots (rainfall plus added water) during the studied growing season

the previous growing season in the southern Khentei Mountains and were stratified at $4{ }^{\circ} \mathrm{C}$ prior to sowing. Under optimum conditions in the laboratory, the germination rate of the seeds was $>90 \%$. Seedling emergence and vitality were checked in the field in mid June, early July, mid July, and mid August after 4, 6,8 , and 12 weeks. Seedling emergence is specified as the proportion of seeds emerged from the each 10 seeds sown per subplot averaged over the 10 subplots per plot; thus, a cumulative rate of seedling emergence was calculated for the 12-week period. 12 weeks after sowing in mid August, the soil was searched for ungerminated seeds where no seedlings had appeared. Seeds not recovered during this search were treated as lost to predation.

\section{Planting experiment}

Forty-eight 2-yr-old seedlings of $P$. sylvestris from the southern Khentei were planted per plot in four rows perpendicularly to the contours lines at a distance of $2 \mathrm{~m}$ from their neighboring seedlings. The 24 seedlings planted in the lower half of the four rows were irrigated twice a week as described above. The vitality of the planted seedlings was assessed 2 weeks after planting in late May and afterward monthly from June to September. The vitality assessment included drought-related damage, feeding damage by insects or rodents, and damage due to fungi-induced needle cast. While the fungi (like Lophodermium, Cyclaneusma) were restricted to the needles, drought- related withering and herbivore damage were observed both in needles and the stem and, therefore, separately monitored. For this purpose, percent values were estimated for the proportion of (1) dry needles without any visible signs of feeding damage or fungal infection, (2) needles consumed by herbivores, (3) needles visibly affected by fungi, (4) stem parts decorticated by herbivores, and (5) desiccated stem parts without visible feeding damage. The percent values were recorded in classes, which were defined as follows: $0,0 \%$ damage; $1, \leq 1 \% ; 2,>1$ to $\leq 5 \% ; 3$, $>5$ to $\leq 25 \% ; 4,>25$ to $\leq 50 \% ; 5,>50$ to $\leq 75 \% ; 6$, $>75$ to $99 \% ; 7,100 \%$. Our monitoring method probably led to moderate overestimation of droughtrelated damage in needles and underestimation of needle cast, because the fungi usually did not form ascocarps during the one growing season under study, but their presence was inferred from characteristic browning patterns of the foliage known for the relevant species (Butin and Kowalski 1989).

Ecophysiological measurements in planted seedlings

In addition to the visual appraisal of seedlings vitality, measurements of the shoot water potential and the chlorophyll fluorescence yield were carried out in the mid growing season. The shoot water potential was measured in seedlings that were planted for this purpose in addition to the seedlings used to monitor survival rates. The seedlings for these measurements were planted in a row parallel to the other rows of seedlings and were not irrigated. The measurements were made on rainless days in June and July with clear sky with a Model 1000 Pressure Chamber Instrument (PMS Instrument Company, Albany, Oregon, U.S.A.) applying the method of Scholander et al. (1964). The measurements were limited to the recording of the midday water potential $\left(\Psi_{\mathrm{m}}\right)$, which equals the daily minimum water potential. These destructive measurements were carried out in four seedlings at each sampling date with five iterative measurements per seedling. Furthermore, pressure-volume curves were recorded on the shoots of three seedlings per sampling date. The pressure-volume curves were used to determine the point of zero turgor $\left(\Psi_{0}\right)$ (Roberts et al. 1980). $\Psi_{0}$ is the maximum value of $\Psi$, above which irreversible damage due to cytorrhysis is possible. However, the point of cytorrhysis can be 
below $\Psi_{0}$ if the elasticity of the cell wall allows negative turgor values.

Measurements of the chlorophyll fluorescence yield were carried out in August in the uppermost needles. The effective quantum yield $\left(\Phi_{2}\right)$ of photochemical energy conversion in photosystem II (PS II) in the light-adapted state was measured with a MiniPAM chlorophyll fluorometer (Walz Mess- und Regeltechnik, Effeltrich, Germany). In addition to $\Phi_{2}$, the photosynthetic photon flux density (PPFD) and the leaf temperature were measured with sensors integrated in the leaf clip holder of the Mini-PAM. PPFD data were used to calculate the electron transport rate $(\mathrm{ETR})$ after the equation ETR = $\Phi_{2} \times$ PPFD $\times 0.42$. The non-photochemical quenching (NPQ) was calculated following the equation $\mathrm{NPQ}=\left(\mathrm{F}_{\mathrm{M}}-\mathrm{F}_{\mathrm{M}}{ }^{\prime}\right) / \mathrm{F}_{\mathrm{M}}{ }^{\prime}$ with $\mathrm{F}_{\mathrm{M}}$ being the absolute maximum fluorescence in the dark-adapted state and $\mathrm{F}_{\mathrm{M}}{ }^{\prime}$ being the absolute maximum fluorescence in the light-adapted state (Roháček 2002). The chlorophyll fluorescence measurements were carried out in ten irrigated and ten non-irrigated randomly selected seedlings on the sample plot near at the forest edge of site B. On the open meadow steppe, most seedlings were already dead at the time of the measurements. Furthermore, light-response curves were recorded in five irrigated and five non-irrigated seedlings from the forest edge plot to establish the maximum value of ETR $\left(\mathrm{J}_{\max }\right)$. Prior to the measurement, these samples were adapted to the dark for $30 \mathrm{~min}$.

\section{Microclimate}

Data of air and soil temperature, volumetric soil water content and precipitation were recorded with $\mathrm{HOBO}$ weather stations equipped with a set of HOBO Smart Sensors (Onset, Bourne, Massachusetts, U.S.A.) throughout the study period. Air temperature at $150 \mathrm{~cm}$ above the ground (temperature/RH sensor S-THA), soil temperature at $1 \mathrm{~cm}$ depth (8 Bit temperature sensor S-TMA), and soil water content at $10 \mathrm{~cm}$ depth (soil moisture sensor S-SMA) were measured on each sample plot. The measurement of rainfall at $1 \mathrm{~m}$ above the ground was limited to the two plots of site A (rain gauge sensor S-RGA). Snow, which was negligible during the study period, was not sampled on the plots, but in five 10-1 buckets on a floodplain meadow of the Eroo valley $2 \mathrm{~km} \mathrm{SW}$ of site B. Measurements with the HOBO weather stations were recorded every $10 \mathrm{~min}$. The individual measurements are means of 10 iterative measurements. For a detailed characterization of the microclimate of the study sites see Dulamsuren and Hauck (2008).

\section{Statistics}

Arithmetic mean \pm standard errors are given throughout the paper. Data were tested for normal distribution with the Shapiro-Wilk test. Significance of differences between more than two means of normally distributed data was tested with Duncan's multiple range test. The impact of site factors on the germination rate at four consecutive dates was analyzed with a repeated measures three-way analysis of variance (ANOVA). After negatively testing for sphericity with Mauchly's test, testing for within-subject effects was limited to multiple analysis of variance (MANOVA) using Wilk's test. Statistical analyses were computed with SAS 9.13 software (SAS Institute Inc., Cary, North Carolina, U.S.A.).

\section{Results}

\section{Microclimate}

In terms of microclimate, the open meadow steppe and the meadow steppe along the forest edge differed more strongly from each other at site A than at site B (Table 1). At site A, soil was clearly warmer and drier in the open steppe than at the forest edge. Furthermore, air temperature in the open steppe exceeded that of the forest edge. At site B, soil temperature in the open steppe was also higher than at the forest edge, but soil was not drier in the former as at site A. Air temperature did not differ between the habitats at site B and reached the same magnitude as in the open steppe at site A.

\section{Seedling emergence and granivory}

Seedling emergence was strongly influenced by the vegetation type (Table 2). Only $2-8 \%$ of the sown seeds emerged as seedlings in the open meadow steppe, whereas this rate was $8-20 \%$ in the meadow steppe along the forest edge (Fig. 3). The difference in the seedling emergence between the two grassland types was more pronounced at site $\mathrm{A}$ than $\mathrm{B}$, as 
indicated by the significant interaction between vegetation type and site in the ANOVA (Table 2). The influence of the site increased over time, as was indicated by the significant within-subject effect of the site. Irrigation had no continuous effect on seedling emergence, but the significance of irrigation increased over time, as seedling emergence became higher on watered than non-watered subplots; this was especially true for the forest edge at site A (Fig. 3a; Table 2). Most seeds were putatively eaten by seed predators; the percentage varied between 66 and $92 \%$ in the open steppe and 52 and $76 \%$ at the forest edge (Fig. 4a). While a high proportion of the seeds which were not eaten germinated and emerged as seedlings on the irrigated subplots at the forest edge (60-80\%), only $20-35 \%$ of the seeds which were not consumed by seed predators led to the emergence of seedlings on the open steppe and in the non-irrigated subplots at the forest edge (Fig. 4b). The rate of emerged seedlings increased with the mean soil water content, but decreased with the mean maximum temperature of the soil in the sample plots during the part of the growing season when seedling emergence was studied (Fig. 5).

\section{Survival of planted seedlings}

Drought-related mortality and fungal infections of the foliage, but only little damage by herbivorous insects or rodents were observed in the planted seedlings of Scots pine. At the end of the study period in September, between 8 and $29 \%$ of the seedlings had stems which were desiccated to more than $75 \%$ (Fig. 6). On average, further $27 \pm 7 \%$ of the seedlings per plot had drought-related damage that extended to $25-75 \%$ of the stem surface. There was no consistent trend across steppe community or in irrigated versus non-irrigated plots.

Drought damage in needles was mostly connected with the colonization by fungi. In up to $50 \%$ of the seedlings, between 25 and $50 \%$ of the needles were dead and had visible signs of a fungal infection from June to August (Fig. 7a, b). In September, the number of trees with $25-50 \%$ of the needles damaged this way declined, partly because the seedlings had to be assigned to a class of more severe damage, the dead needles had dropped off or the whole plant was dead. In the late growing season, the percentage of seedlings where all needles were infected by fungi and had died increased to $50 \%$ in the non-irrigated and to 17-25\% in the irrigated seedlings at site A (Fig. 7c). At site B, seedlings with such damage were much more frequent (63-100\% of the seedlings), except for the irrigated seedlings at the forest egde (Fig. 7d). Seedlings without or with only few dead and fungi-infected needles $(<25 \%)$ were rare. Needle yellowing where a connection to the colonization was not visible only occurred in rare cases. Only in a few non-irrigated

Table 1 Microclimate of sites A and B in the open meadow steppe (OM) and the meadow steppe at the forest edge (FE) during the study period from May to September (153 days) resulting from measurements made every $10 \mathrm{~min}$

\begin{tabular}{|c|c|c|c|c|}
\hline & \multicolumn{2}{|l|}{ Site A } & \multicolumn{2}{|l|}{ Site B } \\
\hline & $\mathrm{OM}$ & $\mathrm{FE}$ & $\mathrm{OM}$ & $\mathrm{FE}$ \\
\hline Air temperature $\left({ }^{\circ} \mathrm{C}\right)^{1}$ & 1,899 & 1,869 & 1,889 & 1,892 \\
\hline Air temperature $\left({ }^{\circ} \mathrm{C}\right)^{2}$ & $12.4 \pm 0.4^{\mathrm{a}}$ & $12.2 \pm 0.5^{\mathrm{a}}$ & $12.4 \pm 0.4^{\mathrm{a}}$ & $12.5 \pm 0.5^{\mathrm{a}}$ \\
\hline Soil temperature $\left({ }^{\circ} \mathrm{C}\right)^{1}$ & 2,616 & 2,175 & 2,667 & 2,596 \\
\hline Soil temperature $\left({ }^{\circ} \mathrm{C}\right)^{2}$ & $17.1 \pm 0.5^{\mathrm{a}}$ & $14.5 \pm 0.4^{\mathrm{b}}$ & $17.5 \pm 0 .^{5 \mathrm{a}}$ & $17.1 \pm 0.5^{\mathrm{a}}$ \\
\hline Min. soil temperature $\left({ }^{\circ} \mathrm{C}\right)^{2}$ & $9.7 \pm 0.5^{\mathrm{a}}$ & $9.5 \pm 0.4^{\mathrm{a}}$ & $10.7 \pm 0.5^{\mathrm{a}}$ & $9.7 \pm 0.4^{\mathrm{a}}$ \\
\hline Absolute min. soil temperature $\left({ }^{\circ} \mathrm{C}\right)$ & -2.9 & -0.2 & -2.4 & -2.4 \\
\hline Max. soil temperature $\left({ }^{\circ} \mathrm{C}\right)^{2}$ & $30.8 \pm 0.9^{\mathrm{a}}$ & $22.0 \pm 0.5^{\mathrm{b}}$ & $27.1 \pm 0.6^{\mathrm{c}}$ & $29.0 \pm 0.7^{\mathrm{c}}$ \\
\hline Absolute max. soil temperature $\left({ }^{\circ} \mathrm{C}\right)$ & 54.1 & 31.1 & 42.0 & 45.9 \\
\hline Soil water content $(\operatorname{vol} . \%)^{2}$ & $5.8 \pm 0.2^{\mathrm{a}}$ & $11.0 \pm 0.2^{\mathrm{b}}$ & $8.3 \pm 0.2^{\mathrm{c}}$ & $7.2 \pm 0.2^{\mathrm{c}}$ \\
\hline
\end{tabular}

1 Sum of daily mean temperatures

${ }^{2}$ Mean values $( \pm$ standard error) are followed by different letters, as they differ significantly $(P \leq 0.05$, Duncan's multiple range test, $\mathrm{df}_{\text {model }}, \mathrm{df}_{\text {error }}=3,600$ ) 
Table 2 Results of repeated measures three-way ANOVA for the rate of seedling emergence from sown Scots pine seeds recorded on four dates depending on the vegetation type (open meadow steppe, meadow steppe along forest edge), irrigation (watering with 11 twice a week in addition to natural precipitation vs. natural precipitation alone), and locality (sites A, B)

\begin{tabular}{|c|c|c|c|c|}
\hline & \multicolumn{2}{|c|}{$\begin{array}{l}\text { Between- } \\
\text { subjects }\end{array}$} & \multicolumn{2}{|c|}{$\begin{array}{l}\text { Within- } \\
\text { subjects }\end{array}$} \\
\hline & $F$ & $P$ & $F$ & $P$ \\
\hline Vegetation type & 7.40 & 0.01 & 1.07 & 0.37 \\
\hline Irrigation & 2.94 & 0.10 & 2.29 & 0.08 \\
\hline Site & 0.50 & 0.49 & 8.69 & $<0.001$ \\
\hline Vegetation type $\times$ irrigation & 2.29 & 0.14 & 2.52 & 0.06 \\
\hline Vegetation type $\times$ site & 4.48 & 0.04 & 1.65 & 0.18 \\
\hline Irrigation $\times$ site & 0.09 & 0.76 & 3.05 & 0.03 \\
\hline
\end{tabular}

$\overline{\text { Between-subjects results } \mathrm{df}=1 \text {, within-subjects results } \mathrm{df}=3}$

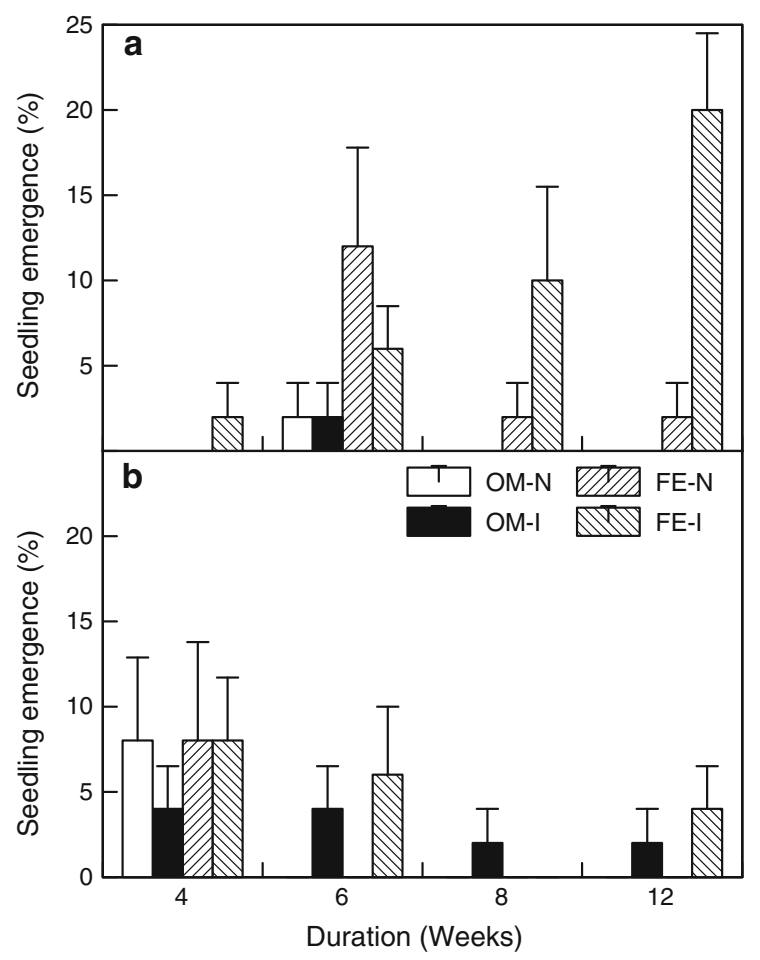

Fig. 3 Seedling emergence of Scots pine from sown seeds 4, 6, 8 , and 12 weeks after sowing at sites A (a) and B (b). Viable individuals present at two subsequent dates are included in the values of either date. Rates of emerged seedlings are related to the total of sown seeds. Arithmetic means \pm standard errors of five subplots per site each with 10 seeds. Treatments: $O M-N$ non-irrigated open meadow steppe; $O M-I$ irrigated open meadow steppe; $F E-N$ non-irrigated meadow steppe along forest edge; $F E-I$ irrigated meadow steppe along forest edge

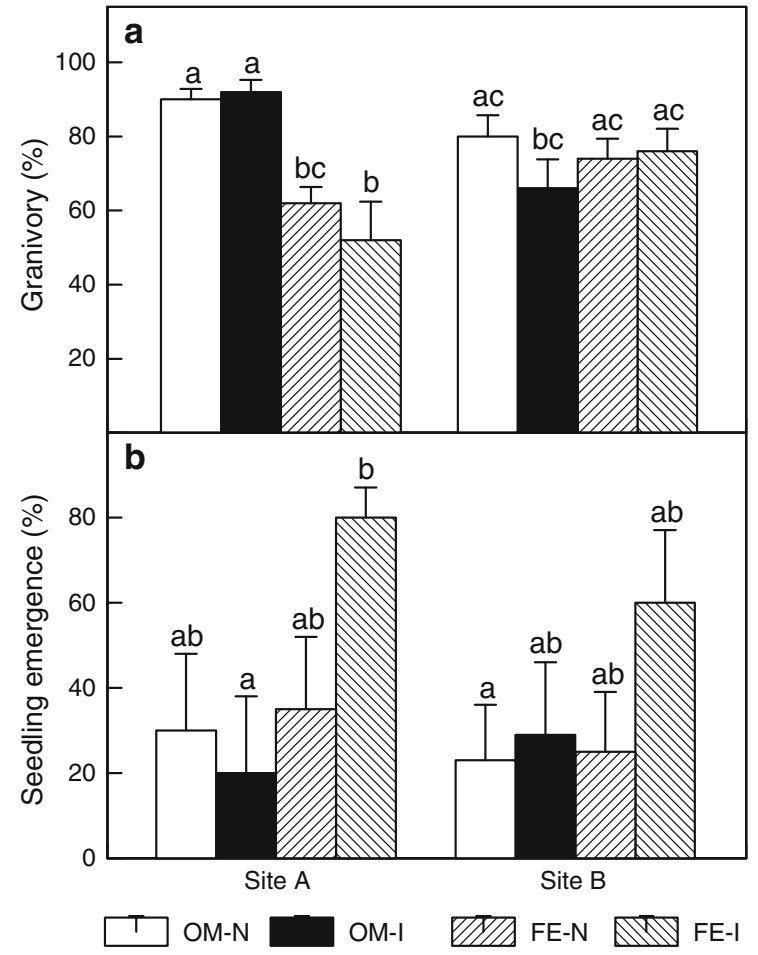

Fig. 4 a Putative loss of Scots pine seeds due to seed predators 12 weeks after sowing at sites A and B. b Rates of emerged seedlings related to all seeds minus the number of seeds putatively removed by seed predators 12 weeks after sowing. Arithmetic means \pm standard error of five subplots per site each with 10 seeds. Means with a common letter do not differ significantly (Duncan's multiple range test, $\mathrm{df}=7, P \leq 0.05$ ). Treatments: $O M-N$ non-irrigated open meadow steppe; $O M-I$ irrigated open meadow steppe; $F E-N$ non-irrigated meadow steppe along forest edge; $F E-I$ irrigated meadow steppe along forest edge

seedlings from the open meadow steppe of site B, more than $50 \%$ or even more than $75 \%$ of the needles were dry without showing signs of fungal colonizers. Many of the green needles were also colonized by fungi. The proportion was highly variable, but was not consistently related to the grassland type or irrigation (Fig. 7e, f).

Feeding damage by herbivorous insects or rodents played little role both in needles and stems. From May to August, feeding damage in needles was virtually absent; only a single seedling in June showed minor damage. Later in September, $1-5 \%$ of the needles were eaten by herbivores in $28 \%$ of the seedlings. More than $25 \%$ of the needles had been eaten in only two seedlings and more than $50 \%$ of the needles were consumed by herbivores in another two seedlings. 

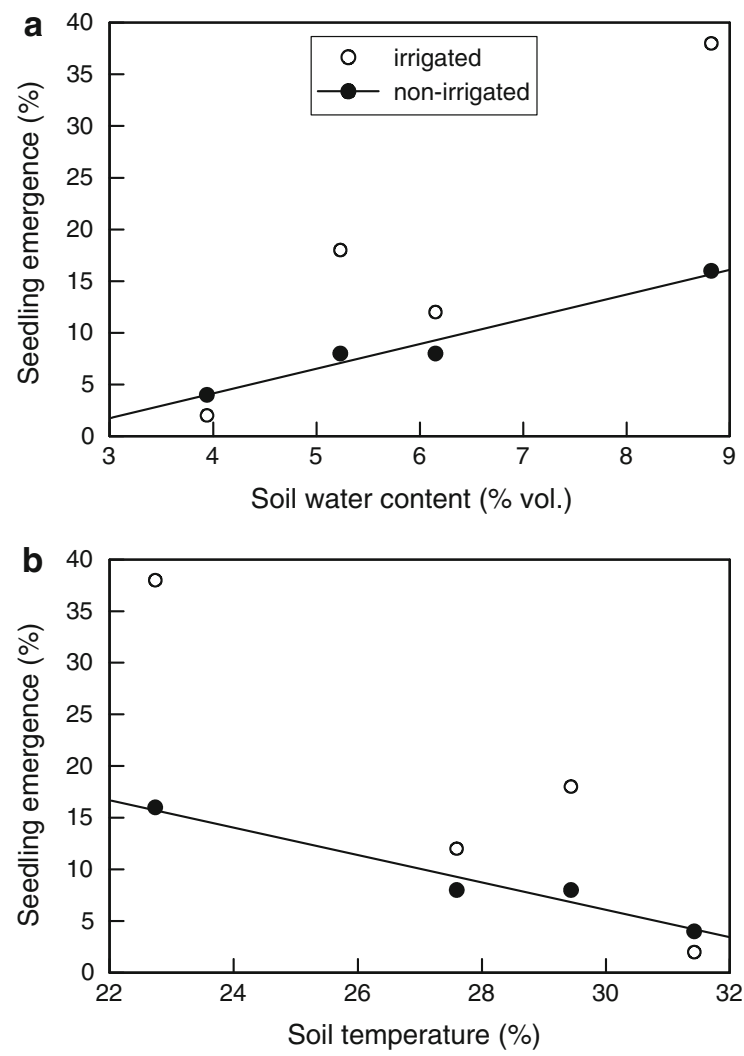

Fig. 5 Cumulative rates of seedling emergence from sown seeds of Scots pine 12 weeks after germination versus a mean soil water content at $10 \mathrm{~cm}$ depth or $\mathbf{b}$ maximum soil temperature at $1 \mathrm{~cm}$ depth. Regression lines are significant $(P \leq 0.05)$ for the non-irrigated seeds: $\mathbf{a} \mathrm{r}=0.98, \mathbf{b} \mathrm{r}=-0.98$. Microclimate data are averaged from measurements made every 10 min throughout the study period

Substantial decortication of the stem by herbivores was only observed in three individuals of Scots pine throughout the entire study period.

Shoot water potential and chlorophyll

fluorescence yield

The midday water potential $\left(\Psi_{\mathrm{m}}\right)$ of non-irrigated seedlings was recorded as $-0.8 \pm 0.1 \mathrm{MPa}$ in June and $-1.1 \pm 0.0 \mathrm{MPa}$ in July. This is far above the point of zero turgor $\left(\Psi_{0}\right)$, which was determined as $-2.2 \pm 0.0 \mathrm{MPa}$ in June and $-2.1 \pm 0.2 \mathrm{MPa}$ in July. Despite identical PPFD and needle temperatures (Fig. 8a, b), the chlorophyll fluorescence yield $\left(\Phi_{2}\right)$ and the ETR were higher in irrigated than nonirrigated pine seedlings (Fig. 8c, d). The ETR showed a marked depression in the early afternoon hours. The

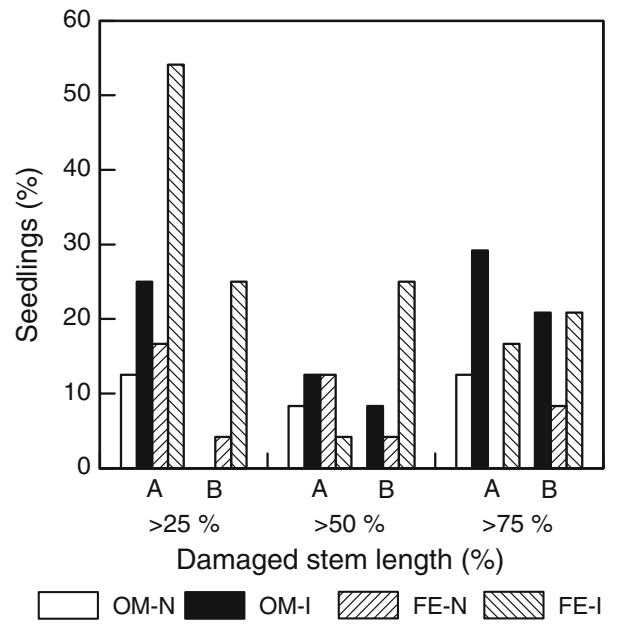

Fig. 6 Planted seedlings of Scots pine with $>25-50 \%,>50-75 \%$, or $>75-99 \%$ of the stem length desiccated at the end of the study period in September. Treatments: $O M-N$ non-irrigated open meadow steppe; OM-I irrigated open meadow steppe; $F E-N$ non-irrigated meadow steppe along forest edge; $F E-I$ irrigated meadow steppe along forest edge

NPQ was higher in the non-irrigated than the irrigated seedlings (Fig. 8e). Light saturation was achieved at a significantly higher level in irrigated than non-irrigated seedlings, as can be deduced from the maximum value of ETR $\left(\mathrm{J}_{\max }\right)$ in Fig. 9.

\section{Discussion}

The results of our sowing and planting experiments suggest that drought, seed predation, and infection by needle-inhabiting fungi are key factors which inhibit the regeneration of Scots pine in Mongolia's foreststeppe ecotone and limit the potential of this tree species to colonize grasslands near to the forest line. The most significant obstacle for seedling emergence was the removal of seeds by seed predators. Losses of 50 to $>90 \%$ of the seeds per plot agree with studies on post-dispersal granivory of Scots pine in dry forests in Spain where up to $96 \%$ of the natural seed production that reached the ground were consumed by rodents and birds (Castro et al. 1999). Post-dispersal losses of seeds found in our experiment were in the same order of magnitude as in the other trees species occurring in northern Mongolia, including Siberian larch (Dulamsuren et al. 2008) and Siberian elm (Ulmus pumila L.) (Dulamsuren et al. 2009b). The high success of seeds which were not consumed by seed predators in 


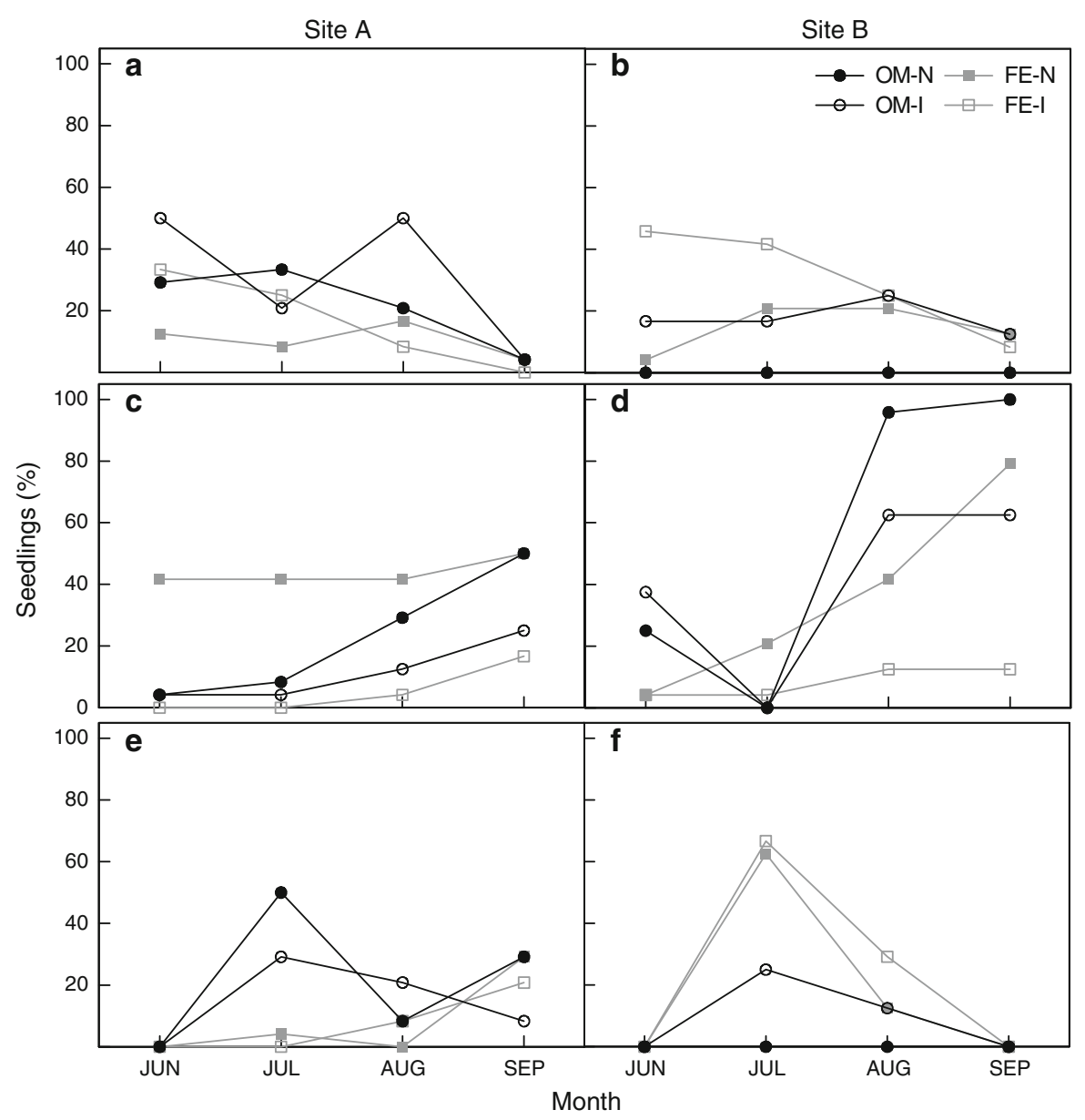

Fig. 7 Planted seedlings with visible infection by pathogenic fungi in planted seedlings of Scots pine in sites A $(\mathbf{a}, \mathbf{c}, \mathbf{e})$ and B $(\mathbf{b}, \mathbf{d}, \mathbf{f})$. Percent of seedlings $\mathbf{a}, \mathbf{b}$ with $25-50 \%$ of live needles with fungal infection, c, d with $25-50 \%$ of needles dead and with fungal infection, $\mathbf{e}, \mathbf{f}$ with all needles dead and with fungal

the irrigated subplots at the forest edge suggests that seedling emergence of Scots pine is well possible in wet years. This assumption is supported by the positive correlation of seedling emergence with soil moisture and the negative correlation with soil temperature in our study, which parallel results from dry forests of Scots pine in Spain (Castro et al. 2005a). The importance of pre-dispersal seed predation in the stands of Scots pine in Mongolia is unknown, but was assessed to exceed $80 \%$ in Spain (Castro et al. 1999). While pre-dispersal removal of ripe seeds may, on the one hand, suppress regeneration (Siepielski and Benkman 2008), on the other hand, it may support it by facilitating its dispersal over longer distances (Vander Wall et al. 2005). Dispersal distances were infection. Treatments: $O M-N$ non-irrigated open meadow steppe; $O M-I$ irrigated open meadow steppe; $F E-N$ non-irrigated meadow steppe along forest edge; $F E$-I irrigated meadow steppe along forest edge

not analyzed by us in our study area, but it was evident that the natural regeneration of (the wind-dispersed) Scots pine was restricted to the immediate vicinity of stands of this species. This field observation matches with estimates for Pinus halepensis and P. koraienis, where most seeds were found to disperse within $15 \mathrm{~m}$ from the source tree (Nathan et al. 2000; Yi et al. 2008).

Once a seedling has emerged, the influence of feeding damage appeared to decrease sharply; herbivore damage was quantitatively unimportant in the planted seedlings. This contrasts with the results of experiments with seedlings of Siberian larch, which were earlier planted on the same sample plots (Dulamsuren et al. 2008). In that species, defoliation 


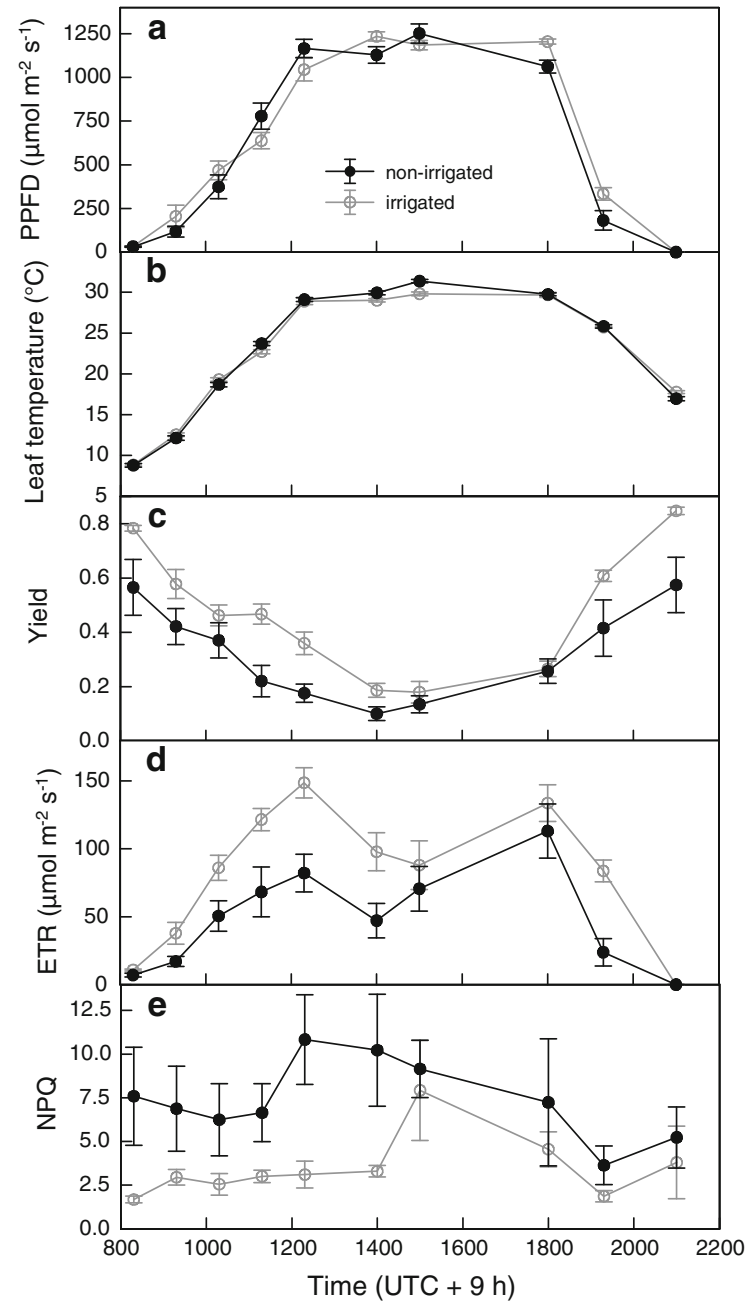

Fig. 8 Diurnal variation of chlorophyll fluorescence parameters each in ten 2-year old seedlings of Scots pine planted at site $\mathrm{B}$ in open meadow steppe and meadow steppe along the forest edge or on a river terrace of the floodplain of the river Eroo. a Photon flux density (PPFD), b leaf temperature, c effective quantum yield $\left(\Phi_{2}\right)$ of photochemical energy conversion in photosystem II, d electron transport rate $(E T R)$, and e nonphotochemical quenching $(N P Q)$. Arithmetic means with error bars for standard error $(N=10)$

in the early growing season by gypsy moth and later by grasshoppers as well as decortication of stems by grasshoppers and rodents were widespread and were estimated to be the cause of mortality in two-thirds of the seedlings. It is likely that the complex chemistry of secondary metabolism in Scots pine was the key factor causing the low susceptibility of this species to herbivorous insects and rodents (Wagner and Evans 1985; Iason et al. 2011). Beninger and Abou-Zaid (1997) substantiated that flavonol glycosides protect

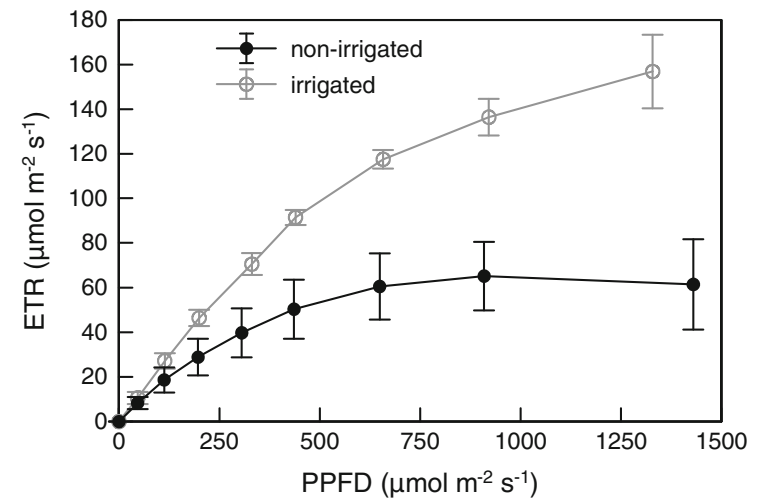

Fig. 9 Light response of the electron transport rate (ETR) in irrigated and non-irrigated 2-year old seedlings of Scots pine from the open meadow steppe in August. Arithmetic means with error bars for standard error $(N=5)$

$P$. sylvestris and other pine species from feeding damage by gypsy moth larvae which defoliated most seedlings and killed many seedlings of Siberian larch in the study of Dulamsuren et al. (2008) and which is also an important factor limiting the growth of mature larch trees in Mongolia (Hauck et al. 2008; Dulamsuren et al. 2010a). Competition by grasses and herbs is another potential factor that could limit the successful establishment of pine in the forest-steppe ecotone (Castro et al. 2002). However, we do not consider it as a key factor in the present case, since a significant influence of competition was not detected, when a comparable experiment was conducted with larch at the same site and the above- and the below-ground competition were manipulated (Dulamsuren et al. 2008).

Drought was clearly limiting the growth and the survival of the pine seedlings in our experiment. Like in mature trees growing in the forest-steppe ecotone (Dulamsuren et al. 2009a), the Scots pine seedlings were capable of maintaining a high shoot water potential far above the point of zero turgor and thus were avoiding the risk of cytorrhysis even in dry periods, but this advantage was gained at the cost of carbon gain. From the chlorophyll fluorescence measurements, it was evident that the seedlings suffered from a reduced photosynthetic electron transport capacity in August, i.e., drought-induced biochemical limitation of their photosynthetic capacity, which must have resulted in reduced carbon gain. Since most yellowed and dead needles were colonized by fungi, it is hard to decide whether drought or the fungal infection was the primary cause of the heavy loss of 
foliage in many seedlings. Probably, needle loss was the result of a combination of both factors, as drought might have increased the susceptibility to fungal infections. The higher amount of green needles with fungal infections in seedlings from the open steppe than the forest edge at site A, where the forest edge was significantly moister than the open steppe, is supportive of this assumption. Castro et al. (2005b) concluded in their study from dry Scots pine forests in Spain that drought was the key factor of seedling mortality without mentioning any effects of phytopathogenic fungi. Since many needle-inhabiting fungi in pine are perennial (Kowalski 1982; Zamora et al. 2008), it cannot be ruled out that seedlings were already infected when they were planted in the early growing season, though they had no visible sign of fungal infections at that time. However, it is not likely that the impact of the phytopathogenic fungi on seedling survival was merely an experimental artifact, as, in the study area, fungal infections of needles were also widespread in Scots pine seedlings from natural regeneration. Moreover, the needles of the planted seedlings had only visible signs of early stages of fungal infection (i.e., characteristic browning patterns), whereas ascocarps, which are indicative of a more progressed fungal infection (Butin and Kowalski 1989), were not visible.

Interpreting the results obtained in the different steppe communities, the deviating microclimatic conditions of the two forest edge plots, which became visible during the measurements, have to be taken into account. At site A, where the grassland at the forest edge was significantly cooler and moister than the open meadow steppe, both seedling emergence and survival were markedly higher at the forest edge than in the open steppe. As shown by the repeated measures ANOVA for seedling emergence, water supply became an increasingly important factor over the growing season at this site because drought stress occurred more frequently in the mid than the early growing season (Dulamsuren et al. 2009c). At site B, seedling emergence and growth were more similar between the open steppe and the forest edge, because of the less pronounced microclimatic contrasts between these two habitats on this mountain slope. An additional factor that was not studied by us which might also have influenced the establishment of Scots pine in the two habitats is the presence of mycorrhizal fungi compatible to Scots pine; they could be more abundant near the forest line than in the open grassland (Öpik et al. 2003). Furthermore, differences in the snowpack between north-facing and south-facing slopes might affect seedling mortality during winter. This was not relevant to our experimental results, but could become effective for the fate of the seedlings on the long run.

\section{Conclusions}

Seed predation, drought, and fungal infections, but not that much herbivorous insects or rodents clearly limit the regeneration of Scots pine in the forest-steppe ecotone of northern Mongolia. The better performance of seedlings on grasslands directly in front of the forest line than on the more distant open steppe and the clear irrigation effects indicate that the potential of Scots pine to encroach onto grasslands in the forest-steppe vegetation mosaic in northern Mongolia is very limited and restricted to the immediate vicinity of the forest, where successful germination is only possible in years which are cooler and moister than the average. The regeneration potential of Scots pine might even decrease in future because of the recent marked increase in aridity in most areas of the Mongolian forest belt as the result of global warming (Dulamsuren et al. 2010b, c). This sensitivity at the seedling stage contrasts with the high drought tolerance of mature Scots pine trees (Dulamsuren et al. 2009a). Herbivory by ungulates was excluded from the study, but might be an important additional factor limiting the regeneration of Scots pine in other areas of Mongolia (Castro et al. 2002; Baraza et al. 2009; Herrero et al. 2012), as grazing of livestock, including increasing numbers of goats, by free-roaming flocks owned by pastoral nomads is widespread in the forest margin zone and frequently also in the forest interior.

Acknowledgments The study was supported by a grant of the German Science Foundation (Deutsche Forschungsgemeinschaft) to Ch. Dulamsuren (Du 1145/1-1). We are thankful to our student assistants from the Biological Faculty of the National University of Mongolia (Ulan Bator) for their help during field work.

Open Access This article is distributed under the terms of the Creative Commons Attribution License which permits any use, distribution, and reproduction in any medium, provided the original author(s) and the source are credited. 


\section{References}

Alia R, Moro-Serrano J, Notival E (2001) Genetic variability of Scots pine (Pinus sylvestris) provenances in Spain. Growth traits and survival. Silva Fenn 35:27-38

Bäck J, Aalto J, Henriksson M, Hakola H, He Q, Boy M (2012) Chemodiversity of a Scots pine stand and implications for terpene air concentrations. Biogeosciences 9:689-702

Baraza E, Hódar JA, Zamora R (2009) Consequences of plantchemical diversity for domestic goat food preference in Mediterranean forests. Acta Oecol 35:117-127

Beninger CW, Abou-Zaid MM (1997) Flavonol glycosides from four pine species that inhibit early instar gypsy moth (Lepidoptera: Lymantriidae) development. Biochem Syst Ecol 25:505-512

Butin H, Kowalski T (1989) Schüttepilze der Kiefern. Merkbl Forstl Versuchs- und Forschungsanstalt Baden-Württemberg 39:1-6

Castro J, Gómez JM, García D, Zamora R, Hódar JA (1999) Seed predation and dispersal in relict Scots pine forests in southern Spain. Plant Ecol 145:115-123

Castro J, Zamora R, Hódar JA (2002) Mechanisms blocking Pinus sylvestris colonization of Mediterranean mountain meadows. J Veg Sci 13:725-731

Castro J, Zamora R, Hódar JA, Gómez JM (2004) Seedling establishment of a boreal tree species (Pinus sylvestris) at its southernmost distribution limit: consequences of being in a marginal Mediterranean habitat. J Ecol 92:266-277

Castro J, Zamora R, Hódar JA, Gómez JM (2005a) Ecology of seed germination of Pinus sylvestris L. at its southern, Mediterranean distribution range. Investigación Agraria: Sistemas y Recursos Forestales 14:143-152

Castro J, Zamora R, Hódar JA, Gómez JM (2005b) Alleviation of summer drought boosts establishment success of Pinus sylvestris in a Mediterranean mountain: an experimental approach. Plant Ecol 181:191-202

Debain S, Curt T, Lepart J, Prevosto B (2003) Reproductive variability in Pinus sylvestris in southern France: implications for invasion. J Veg Sci 14:509-516

Dulamsuren Ch (2004) Floristische diversität, Vegetation und standortbdingungen in der Gebirgstaiga des Westkhentej, Nordmongolei. Ber Forschungszentr Waldökosyst A 191:1-290

Dulamsuren Ch, Hauck M (2008) Spatial and seasonal variation of climate on steppe slopes of the northern Mongolian mountain taiga. Grassland Sci 54:217-230

Dulamsuren Ch, Hauck M, Mühlenberg M (2005) Ground vegetation in the Mongolian taiga forest-steppe ecotone does not offer evidence for the human origin of grasslands. Appl Veg Sci 8:149-154

Dulamsuren Ch, Hauck M, Mühlenberg M (2008) Insect and small mammal herbivores limit tree establishment in northern Mongolian steppe. Plant Ecol 195:143-156

Dulamsuren Ch, Hauck M, Bader M, Oyungerel Sh, Osokhjargal D, Nyambayar S, Leuschner C (2009a) The different strategies of Pinus sylvestris and Larix sibirica to deal with summer drought in a northern Mongolian forest-steppe ecotone suggest a future superiority of pine in a warming climate. Can J For Res 39:2520-2528

Dulamsuren Ch, Hauck M, Nyambayar S, Osokhjargal D, Leuschner C (2009b) Establishment of Ulmus pumila seedlings on steppe slopes of the northern Mongolian mountain taiga. Acta Oecol 35:563-572

Dulamsuren Ch, Hauck M, Bader M, Osokhjargal D, Oyungerel Sh, Nyambayar S, Runge M, Leuschner C (2009c) Water relations and photosynthetic performance in Larix sibirica growing in the forest-steppe ecotone of northern Mongolia. Tree Physiol 29:99-110

Dulamsuren Ch, Hauck M, Leuschner HH, Leuschner C (2010a) Gypsy moth-induced growth decline of Larix sibirica in a forest-steppe ecotone. Dendrochronologia 28:207-213

Dulamsuren Ch, Hauck M, Leuschner C (2010b) Recent drought stress leads to growth reductions in Larix sibirica in the western Khentey, Mongolia. Glob Change Biol 16:3024-3035

Dulamsuren Ch, Hauck M, Khishigjargal M, Leuschner HH, Leuschner C (2010c) Diverging climate trends in Mongolian taiga forests influence growth and regeneration of Larix sibirica. Oecologia 163:1091-1102

Ellenberg H, Leuschner C (2010) Vegetation Mitteleuropas mit den Alpen, 6th edn. Ulmer, Stuttgart

Hauck M, Dulamsuren Ch, Heimes C (2008) Effects of a gypsy moth invasion on the performance of Larix sibirica in a forest-steppe ecotone of northern Mongolia. Environ Exp Bot 62:351-356

Herrero A, Zamora R, Castro J, Hódar JA (2012) Limits of pine forest distribution at the treeline: herbivory matters. Plant Ecol 213:459-469

Hódar JA, Zamora R, Castro J, Gómez JM, García D (2008) Biomass allocation and growth responses of Scots pine saplings to simulated herbivory depend on plant age and light availability. Plant Ecol 197:191-202

Holtmeier F-K, Broll G (2011) Response of Scots pine (Pinus sylvestris) to warming climate at its altitudinal limit in northernmost subarctic Finland. Arctic 64:269-280

Hultén E, Fries M (1986) Atlas of North European vascular plants: north of the Tropic of Cancer. Vol 1-3. Koeltz, Königstein

Iason GR, O'Reilly-Wapstra JM, Brewer MJ, Summers RW, Moore BD (2011) Do multiple herbivores maintain chemical diversity of Scots pine monoterpenes? Phil Transact Roy Soc B 366:1337-1345

Kauhanen M, Vainio EJ, Hantula J, Eyjolfsdottir GG, Niemelä P (2006) Endophytic fungi in Siberian larch (Larix sibirica) needles. For Pathol 36:434-446

Kowalski T (1982) Fungi infecting Pinus sylvestris needles of various ages. Eur J For Pathol 12:182-190

Lkhagvadorj D, Hauck M, Dulamsuren Ch, Tsogtbaatar (2013) Pastoral nomadism in the forest-steppe of the Mongolian Altai under a changing economy and a warming climate. J Arid Environ 88:82-89

Nathan R, Safriel UN, Noy-Meir I, Schiller G (2000) Spatiotemporal variation in seed dispersal and recruitment near and far from Pinus halepensis trees. Ecology 81:2156-2169

Núñez MR, Calvo L (2000) Effect of high temperatures on seed germination of Pinus sylvestris and Pinus halepensis. For Ecol Manag 131:183-190

Öpik M, Moora M, Liira J, Kljalg U, Zobel M, Sen R (2003) Divergent arbuscular mycorrhizal fungal communities colonize roots of Pulsatilla spp. in boreal Scots pine forest and grassland soils. New Phytol 160:581-593 
Ranta H, Saloniemi I (2005) Distribution of fungal foliage and shoot pathogens in a natural Scots pine population in relation to environmental variables. Can $\mathbf{J}$ For Res 35:503-510

Rehfeldt GE, Tchebakova NM, Parfenova YI, Wykoff WR, Kuzmina NA, Milyutin LI (2002) Intraspecific responses to climate in Pinus sylvestris. Glob Change Biol 8:912-929

Roberts SW, Strain BR, Knoerr KR (1980) Seasonal patterns of leaf water relations in four co-occurring forest tree species: parameters from pressure-volume curves. Oecologia 46:330-337

Roháček K (2002) Chlorophyll fluorescence parameters: the definitions, photosynthetic meaning, and mutual relationships. Photosynthetica 40:13-29

Savin EN, Ogorodnikov AV, Semechkin IV, Dugarzhov Ch, Korotkov IA (1978) Forests of the Mongolian People's Republic. Nauka, Moscow in Russian

Scalfi M, Piotti A, Rossi M, Piovani P (2009) Genetic variability of Italian southern Scots pine (Pinus sylvestris L.) populations: the rear edge of the range. Eur J For Research 128:377-386

Schlütz F, Dulamsuren Ch, Wieckowska M, Mühlenberg M, Hauck M (2008) Late Holocene vegetation history suggests natural origin of steppes in the northern Mongolian mountain taiga. Palaeogeogr Palaeoclimatol Palaeoecol 261:203-217

Scholander PF, Hammel HT, Hemmingsen EA, Bradstreet ED (1964) Hydrostatic pressure and osmotic potential in leaves of mangroves and some other plants. Proc Nat Acad Sci USA 52:119-125

Siepielski AM, Benkman CW (2008) Seed predation and selection exerted by a seed predator influence subalpine tree densities. Ecology 89:2960-2966
Tsogtbaatar J (2004) Deforestation and reforestation needs in Mongolia. For Ecol Manag 201:57-63

Turdieva M, Aleksandrovskiy E, Kayimov A, Djumabaeva S, Mukanov B, Saparmyradov A, Akmadov K (2007) Forests in Central Asia: current status and constraints. In: Lal R, Suleimenov BA, Steward BA, Hansen DO, Doraiswamy P (eds) Climate change and terrestrial carbon sequestration in Central Asia. Taylor \& Francis, London, pp 25-32

van Gardeningen PR, Grace J, Jeffree CE (1991) Abrasive damage by wind to the needle surfaces of Picea sitchensis (Bong.) Carr. and Pinus sylvestris L. Plant Cell Environ 14:185-193

Vander Wall SB, Kuhn KM, Beck MJ (2005) Seed removal, seed predation, and secondary dispersal. Ecology 86:801-806

Wagner MR, Evans PD (1985) Defoliation increases nutritional quality and allelochemics of pine seedlings. Oecologia 67:235-237

Wang XR, Szmidt AE, Lindgren D (1991) Allozyme differentiation among populations of Pinus sylvestris L. from Sweden and China. Hereditas 114:219-226

Wang LL, Shao XM, Huang L, Liang EY (2005) Tree-ring characteristics of Larix gmelinii and Pinus sylvestris var. mongolica and their response to climate in Mohe China. Acta Phytoecol Sin 29:380-385

Yi X, Xiao Z, Zhang Z (2008) Seed dispersal of Korean pine Pinus koraiensis labeled by two different tags in a northern temperate forest, northeast China. Ecol Res 23:379-384

Zamora P, Martínez-Ruiz C, Diez JJ (2008) Fungi in needles and twigs of pine plantations from northern Spain. Fung Divers 30:171-184 